\title{
PENDIDIKAN ISLAM DI MESIR DAN MALAYSIA DI ERA GLOBALISASI KAJIAN PSIKOLOGI POSITIF
}

\author{
Saliyo \\ IAIN Kudus, Jawa Tengah, Indonesia \\ saliyo41876@gmail.com
}

\begin{abstract}
ISLAMIC EDUCATION IN EGYPT AND MALAYSIA IN GLOBALIZATION ERA OF POSITIVE PSYCHOLOGICAL STUDIES. This research was conducted to investigate the implementation of Islamic education in Egypt and Malaysia in globalization era in the study of positive psychology. This study is a qualitative study that examines the literature by reviewing the source of reading books and journals. The method used to analyze this study was inductive deductive thinking patterns.The results showed that along with the challenges ofglobalization era, muslim-majority states in Egypt carried out education in their countries by adopting a secular education system and an Islamic system. Similarly Malaysia that has multi-racial, multi-cultural and multi-religious citizens also adheres to the traditional education system and modern education. Both countries carried out Islamic education well. As the government organizersboth in Egypt and Malaysia who are able to carry out a good Islamic education, meaning that thosepeople in the study of positive psychology are people who have a positive personality and positive thinking in the perspective of positive psychology.
\end{abstract}

Keywords: Islamic Education, Globalization Era, and Positive Psychology. 


\begin{abstract}
Abstrak
Penelitian ini dilakukan untuk mengetahui pelaksanaan pendidikan Islam di Mesir dan Malaysia di era globalisasi dalam kajian psikologi positif. Penelitian ini merupakan penelitian kualitatif mengkaji literatur dengan cara mereview sumber bacaan buku dan jurnal. Metode yang digunakan untuk menganalisis penelitian ini adalah pola berpikir deduktif induktif. Hasil penelitian menunjukkan bahwa seiring dengan tantangan zaman di era globalisasi, Negara yang mayoritas muslim di Mesir melaksanakan pendidikan di Negaranya dengan menganut sistem pendidikan sekuler dan sistem Islam. Begitu juga di Malaysia yang memiliki warga Negara multi ras, multi budaya dan multi agama menganut sistem pendidikan tradisional dan pendidikan modern. Kedua Negara tersebut melaksanakan pendidikan Islam dengan baik. Sebagai penyelenggara pemerintahan baik di Mesir maupun di Malaysia yang mampu melaksanakan pendidikan Islam yang baik, berarti pelaku orang tersebut dalam kajian psikologi positif merupakan orang-orang yang memiliki kepribadian positif dan berpikir positif dalam perspektif psikologi positif.
\end{abstract}

Kata kunci: Pendidikan Islam, Era Globalisasi, dan Psikologi Positif.

\title{
A. Pendahuluan
}

Memperdalam tentang keadaan pendidikan di dunia dapat membaca laporan Educational For All (EFA) 2000-2015 Achievement and Challengges. Untuk periode masa anak-anak ada pencegahan penurunan tingkat kematian pada anak-anak di bawah umur 5 tahun pada tahun 2013. Laporan menunjukan bahwa paling tidak ada 53\% dari 6.3 juta anak-anak yang tingkat kematiannya dapat dicegah. Hal tersebut dibuktikan ada peningkatan kemajuan pada asupan nutrisi anak-anak. Secara global di dunia 1 banding 4 anak yang masih mengalami kekurangan nutrisi. Ada peningkatan yang signifikan pada tahun 1999 dibandingkan tahun 2012 anak-anak yang mau mendaftar pada pendidikan dasar. Tahun 2012 ada 184 anak-anak yang mendaftarkan sekolah pendidikan dasar di seluruh dunia (Prinsloo et al, 2015: XII-XIV).

Menurut Abdalla et al, (2006: v) definisi pendidikan Islam dapat dilihat dari berbagai sudut pandang. Beberapa ahli berpendapat bahwa pendidikan Islam menekankan pada istilah 
tarbiyah. Pendapat yang lain bahwa pendidikan Islam pendidikan yang berkaitan dengan agama dan berdasarkan al-Qur'an dan Hadist. Sisi lain apabila hendak menelaah tentang pendidikan Islam akan lebih baik apabila terlebih dahulu menelaah akar sejarah politik dunia Islam dan implikasinya terhadap sosial dan budaya. Dunia Islam mengalami kesadaran adanya pentingnya transformasi pendidikan ketika telah datangnnya penjajahan Westernisasi pada abad 18/19. Setelah kejadian tersebut umat Islam baru bangkit dari keterlelapan tidurnya bahwa umat Islam merasa penting untuk melawan adanya pengaruh modernisasi ataupun westernisasi pada abad 19. Era tersebut merupakan masa perlawanan orang-orang Islam terhadap superioritas militer, ekonomi dan politik Barat.

Dalam bahasa Arab ilmu berasal dari kata 'ilmu. Ilmu dalam bahasa Ingris memiliki dua makna yaitu knowledge dan science. Namun science dalam bahasa Arab memiliki makna yang lebih jelas lagi. Sebagai contoh sosiologi 'ilmu ijtima', biologi 'ilmu hayat', teologi 'ilmu kalam', ilmu agama 'ilmu ad-din', dan psikologi 'ilmu an-nafs'. Di Barat knowledge lebih dikenal dengan istilah ilmu yang empirik statistik dan mengikuti kaidahkaidah metodologi ilmiah. Di antaranya adalah ilmu kimia, geologi. Knowledge secara empirik digunakan pada istilah ilmu pengetahuan yang bersifat materi. Berbeda dengan hal-hal yang metaphisik ataupun spiritual. Sayyed Hossen Nasr pendapat bahwa science itu suci. Menurut Gifford ilmu secara umum sesuatu yang suci berkaitan dengan keabadian dan alam. Lebih luas ilmu berkaitan dengan transendental (Goddadr, 2012: 4). Allah swt berfirman dalam surat al-Imran (3: 110).

Artinya :Kamu adalah umat yang terbaik yang dilahirkan untuk manusia, menyuruh kepada yang ma'ruf dan mencegah dari yang mungkar dan beriman kepada Allah. Sekiranya Ahli Kitab beriman, tentulah itu lebih baik bagi mereka, di antara mereka ada yang beriman, dan kebanyakan mereka adalah orang-orang yang fasik (al-Imran, 3: 110).

Pendidik dalam melaksanakan kegiatan pembelajaran yang baik sebaiknya berjalan seiring dengan era globalisasi. Menurut Kayadibi \& Buang (2011: 84) konsep globalisasi 
membawa dunia untuk memahami dunia dengan pemahaman yang baru. Era globalisasi dapat meningkatkan hubungan antar Negara dalam dunia yang tidak dapat diabaikan. Secara lebih nyata bagaimana posisi atau peran Islam dalam dunia globalisasi. Islam sebaiknya menempatkan diri untuk dapat bekerja secara simultan untuk meningkatkan peran Islam secara universal dalam kancah global. Manusia diciptakan oleh Allah dengan jenis kelamin lakilaki dan perempuan, berbangsa-bangsa, berbudaya. Manusia yang paling mulia adalah manusia yang takwa. Allah swt berfirman dalam al-Qur'an surat Al-Hujurat (49: 13).

Artinya :Hai manusia sesungguhnya Kami menciptakan kamu dari seorang laki-laki dan perempuan, dan menjadikan kamu berbangsa-bangsa dan bersuku-suku supaya kamu saling kenal mengenal. Sesungguhnya orang-orang yang paling mulia dihadapan Allah adalah orang yang paling bertaqwa di antara kamu. Sesungguhnya Allah Maha Mengetahui lagi Maha Mengenal (Al-Hujurat, 49: 13).

Memahami istilah globalisasi merupakan karya cipta kreativitas manusia. Globalisasi dimulai dari sebuah desa dan meluas melalui pojok-pojok dunia. Sekarang setiap manusia duduk di pojok-pojok pedesaan, mereka dapat mengakses mendapatkan informasi diseluruh dunia karena adanya kemajuan teknologi. Hal yang demikian dengan perbedaan budaya, bahasa, kulit, agama secara fisik dan spiritual manusia dapat menembus setiap wilayah yang paling kecil di dunia (Kayadibi \& Buang, 2011: 84-85).

Menurut Ward \& Schwartz et al (2004: 86-87) bahwa manusia sekarang hidup dalam masa kebebasan dan memiliki otonomi untuk menentukan pilihan hidup. Pilihan-pilihan tersebut memiliki implikasi dan tujuan untuk kesejahteraan psikologis ataupun jasmani setiap manusia itu sendiri. Ilmu psikologi di masa yang akan datang dalam menghadapi hal yang demikian sebaiknya tidak membahas efek negatif dari era globalisasi. Namun bagaimana ilmu psikologi berfungsi secara optimal mampu mengidentifikasi hal-hal yang positif dari ketidak leluasan ketika seseorang diri menentukan pada masalah-masalah yang sangat krusial. Pilihan-pilihan perilaku individu dalam keadaan yang demikian dikaji dalam ilmu psikologi positif. 
Mengkaji psikologi positif bukanlah sesuatu hal tabu. Perkembangan ilmu psikologi terus berkembang regresif. Dulu ilmu psikologi dikenal dengan kajian-kajian pada simtomsimtom negatif yang ada pada manusia. Simtom-simtom tersebut mengakibatkan adanya perilaku negatif. Selanjutnya seiring dengan perkembangan budaya, teknologi, ternyata manusia melupakan potensi apa yang ada pada manusia. Potensi tersebut adalah potensi positif. Potensi positif yang dimiliki oleh oleh manusia tersebut apabila digunakan secara maksimal pada tempat yang tepat dan dibina dengan baik dapat menjadi bermanfaat bagi dirinya dan orang lain.

Menurut ilmuan psikologi penggagas tentang psikologi positif yaitu Snyder \& Lopez menjelaskan bahwa psikologi positif merupakan gagasan baru dan metode baru untuk menemukan potensi yang ada pada manusia. Potensi-potensi tersebut dapat difungsikan dengan secara maksimal dengan cara dibina dengan baik dan disalurkan pada tempatnya yang tepat pada sesuatu yang positif. Tujuannya adalah untuk membina dan mengetahui kekuatan yang positif yang dimiliki oleh setiap manusia agar dapat tumbuh berkembang dengan baik. Dalam dunia pendidikan tokoh-tokoh ilmuan psikologi positif yang banyak digunakan di antaranya adalah Athur Comb, Carl Rogers, dan Abraham Maslow dan lain sebagainya (Saliyo, 2017: 9).

Ada jurnal psikologi positif yang menarik yang dikaitkan dengan pendidikan positif. Jurnal tersebut mengangkat tema tentang The positive educational practices framework: A tool for facilitating the work of educational psychologist in promoting pupil well being. Jurnal tersebut mengkaji bagaimana pendidikan bergandengan dengan psikologi positif untuk bekerja memfasilitasi dan mengorganisasi kerja-kerja psikologi pendidikan untuk mempromosikan kesejahteraan psikologis anak didik (well being) dan memberikan dukungan pada anak didik untuk berprestasi dalam perilaku sosial. Dalam jurnal tersebut diistilahkan dengan The Positive Educational Practices (PEPs). Dalam jurnal tersebut dijelaskan dengan cara memfasilitasi anak didik untuk mengembangkan potensi positif yang dimilikinya dengan cara menerapkan teori-teori psikologi 
positif. Sebagai contoh mengaplikasikan pada anak didik dengan cara mengurangi problem yang dihadapinya dan memberikan perlakukan (treatment) dan mencegahnya pada pengalamanpengalaman negatif menjadi hal yang positif serta pengalaman positif menjadi sumber kekuatan yang jika dibina menjadi prestasi baginya. Perlakuan dan pencegahan dilakukan secara intensif agar anak didik dapat menemukan kesejahteraan psikologi dan dapat melakukan daya tahan hidup yang kuat (resilience). Treatment dan preventive dilakukan berdasarkan tema-tema psikologi positif. Tema - tema tersebut yaitu kompetensi sosial dan emosi, emosi positif, hubungan positif, memupuk anak didik untuk menemukan makna hidup, tujuan hidup yang diarahkan pada pencapaian prestasi (Noble \& McGrath, 2008: 119).

Menurut (Hasyim, 2014: 177-178) bahwa reformasi pendidikan Islam telah dimulai sejak Islam berinteraksi dengan Barat pada abad 18. Ketika masa tersebut Islam sedang mengalami lemah dalam bidang materi ekonomi karena kolonial Barat. Di antara tokoh-tokoh reformasi pendidikan Islam adalah Muhamad Abduh di Mesir, Sayyid Akhmad Khan di India, dan Mahmud Yunus di Indonesia. Reformasi pendidikan Islam yang dilakukan oleh para sarjana mencoba untuk menanggapi kondisi dalam konteks nasional. Sebagai contoh di Mesir Muhamad Abduh mencari perubahan eksistensi pendidikan di institusi. Dia melakukan reformasi khususnya kurikulum di Universitas alAzhar. Dia ingin memperkenalkan ilmu pengetahuan modern. Penelitian yang rasional akan membawa pola pikir sarjana muslim pada wawasan baru pada komunitas muslim, bukan hanya belajar pada potongan-potong teks seperti Ibnu Khaldun.

Di India, ada pembaharu pendidikan Sir Sayyid Akhmad Khan. Akhmad Khan mencoba membuat inovasi dari ideidenya tentang orientasi pendidikan baru di The Muslim Anglo Oriental College. Dia mencoba mengkombinasikan ilmu-ilmu Islam dengan ilmu modern. Tujuannya agar umat Islam mampu bersaing dengan ilmuan Hindu India yang di dukung oleh Inggris. Walaupun demikian uji cobanya mengalami kegagalan. Namun dia sukses membuat generasi perubahan di Pakistan. Di Indonesia ada tokoh pada masa itu yaitu Mahmud Yunus. Dia berusaha 
mengintegrasikan antara kurikulum yang bermuatan Islam pada sekolah-sekolah Belanda yang ada di Sumatra. Usaha tersebut dilakukan secara terus menerus sampai Indonesia mendapatkan kemerdekaannya.

Setelah merdeka banyak Negara-negara muslim di dunia mulai mempetakan permasalahan pendidikan di dunia. Pada tahun 1977 pertama kali dilaksanakan konferensi pendidikan Islam se-dunia di Mekah. Isu yang muncul adalah siap siaga ditingkat dunia bahwa umat Islam siap menghadapi leberalisasi, sekularisasi yang masuk dalam sistem pendidikan Islam. Sisi lain sistem pendidikan Islam juga konservatif tradisional religius. Selanjutnya dualisme sistem pendidikan di Negara-negara muslim merajalela yaitu antara tradisional konservatif religius dan sekuler liberal. Kondisi yang demikian menjadikan konflik pada lulusan pendidikan sebuah institusi pendidikan di Negara-negara muslim, apakah akan menganut sistem pendidikan liberal sekuler, ataupun tradisional konservatif agamis?.

Peneliti memilih mereview pendidikan Islam Negara Mesir dan Malaysia karena memiliki beberapa alasan. Pertama warga Negara Indonesia banyak yang belajar agama Islam di Mesir. Kedua Mesir banyak melahirkan tokoh pembaharu Islam. Peneliti juga memilih pendidikan Islam Negara Malaysia dengan beberapa alasan. Pertama banyak warga Negara Indonesia yang belajar di Negara tersebut. Kedua Negara tersebut memiliki warga Negara yang multikultural, dan sebagian besar penduduknya beragama Islam. Baik Negara Mesir ataupun Malaysia pengelolaan pendidikannya sangat baik.

\section{B. Pembahasan}

Menurut Roubaie bahwa modern dipahami dengan sangat sederhana yaitu perluasan aktivitas ekonomi pada lintas politik dan tanpa batas-batas bangsa. Hal yang demikian dinamakan era globalisasi. Menurut Bukhari bahwa globalisasi juga dipahami sebagai memperkenalkan relasi manusia yang baru yang menyebabkan pandangan baru pada dunia dengan berbagai variasi dari setiap kelompok yang ada pada suatu bangsa. Apabila dipahami secara mendalam globalisasi juga tidak hanya dipahami 
dalam kegiatan ekonomi saja, tetapi juga dipahami dalam kegiatan pendidikan, teknologi informasi, pengetahuan, layanan profesional dan personal.

Ide globalisasi sebenarnya karena ketidaktahuan banyak orang pada budaya, bangsa, agama antara Negara yang satu dengan Negara yang lain. Namun ada yang mengesankan bahwa globalisasi merupakan perluasan kolonialisme dari berbagai bagian dan variasi melalui budaya, agama dan bahasa di Eropa, yang akan menjadikan masyarakat yang mengglobal dalam budaya dan siap untuk diketahui menjadi konsumsi pengetahuan publik (Kayadibi \& Buang, 2011: 85-86).

\section{Mesir}

Mengkaji pendidikan di dunia Islam, maka tidak bisa ketinggalan ketika penulis menyajikan pendidikan yang ada di Mesir. Negara Mesir dalam melaksanakan program pendidikannya menganut dua program sistem. Pertama Mesir melaksanakan pendidikan dengan program sistem sekuler. Kedua Mesir melaksanakan pendidikannya dengan mengambil sistem Islam. Sistem yang terakhir dikomandoi di Universitas al-Azhar. Pemerintahan Mesir mencanangkan wajib belajar sampai tingkat delapan pada pendidikan dasar.

Hal yang sangat mengesankan bahwa rasio warga Negara Mesir yang mendaftar pada pendidikan menengah sampai 67 $\%$. Sisi lain bahwa sisanya ada $43 \%$ orang dewasa yang tidak mendaftar pada pendidikan menengah. Hasil tersebut juga menunjukkan orang yang dewasa yang mengalami buta huruf. Isu yang tidak ketinggalan bahwa rata-rata yang masuk dalam $43 \%$ adalah kaum perempuan. Walaupun keadaan demikian Mesir termasuk Negara yang mencanangkan pendidikan untuk semua (PPC ISUE Working Paper No.1, 2004: 29).

Gamal Abdul Nassir beliau tokoh yang memiliki kharisma yang tinggi dari Mesir. Untuk mengenang kebesarannya masyarakat Mesir menjadikan namanya pada sebuah jalan. Sisi lain Gamal Abdul Nassir atau dikenal dengan nama "Ya'ish Nasser" memiliki makna "Long Live Nasser" hidup yang panjang atau dikenal pada sepanjang zaman. Pemikiran-pemikirannya memberikan inspirasi 
pada tokoh generasi-generasi muslim yang cukup berlian dan dikenal dunia yaitu Anwar Sadat dan Husni Mubarok.

Sebagai bagian dari revolusi nasional Gamal Abdul Nassir sangat memperhatikan pada tema-tema berkaitan dengan isu-isu pendidikan. Setiap pagi warga Negara Mesir bersegera duduk manis mendengarkan siaran radio baik dari kalangan menengah ataupun bawah. Sambil kopi pagi ataupun sarapan pagi warga Negara Mesir mendengarkan ceramah Gamal Abdul Nassir. Kesempatan tersebut khusus pada hari yang dinamakan "Idil al-ilmu, atau "Celebration of Knowledge Day" hari perayaan ilmu pengetahuan. Kegiatan tersebut di mulai sejak tahun 1965 dilaksanakan di Auditorium Universitas Kairo Mesir. Acara tersebut menjelaskan bagaimana keterkaitan antara pendidikan dan tujuan revolusi.

Revolusi juga di kenal dengan al-Thrawah. Revolusi bukanlah suatu ekpresi perasaan warga Negara Mesir. Revolusi benar-benar memiliki makna ilmu pengetahuan dapat mendapatkan semua. Dengan ilmu pengetahuan masayarakat Mesir tidak hanya berubah secara emosinya untuk bereaksi saja, tetapi masyarakat Mesir menemukan makna dan kepuasan atas eksistensinya. Terlebih lagi masyarakat dengan ilmu pengetahuan dapat menyelesaikan problematika kehidupannya baik dari sisi kesejahteraan sosial ataupun kesejahteraan ekonomi. Gamal Abdul Nassir menjadi aikon di Mesir bahwa pendidikan membawa pencerahan ataupun lentera bagi warga negaranya (Mardman et al, 2011: 30-31).

\section{a. Sistem pendidikan umum yang dianut di Mesir}

Sebelum abad 19 para pemimpin dan pemuka agama di Mesir selalu mengontrol sistem pendidikan tradisi yang ada. Pada saat itu Negara mengatur pendidikan dengan mementingkan tema-tema teologi dengan mengadakan seminar-seminar di Gereja ataupun di Masjid. Namun sisi lain di desa-desa terselenggara lembaga pendidikan untuk anak-anak dengan menitikberatkan pada membaca dan menulis Arab, belajar aritmatika dan menghafal ayat demi ayat dari firman Tuhan di Kitab Injil ataupun firman Allah yang ada dalam al-Qur'an. Selanjutnya pada masa Muhamad Ali di abad 19, dia memulai menetapkan sistem pendidikan sekuler 
dengan mempelajari ilmu teknik dan administrasi pemerintahan serta militer.

Ide gagasan besar Muhamad Ali diteruskan dan dikembangkan oleh cucunya yang laki-laki yang bernama Ismail. Ismail terus berjuang mengembangkan kerjasama pendidikan dengan antar sekolah-sekolah pada tingkat dasar, menengah, dan tinggi. Istrinya Ismail juga mendukung perjuangan suaminya dengan mendirikan sekolah perempuan pada tahun 1873. Di antara tahun 1882 dan 1922, Mesir berada di bawah kekuasaan Inggris, maka tokoh - tokoh tersebut berhenti untuk sementara waktu dalam perjuangan perluasan pendidikan. Ketika kekuasaan Inggris berakhir, maka pemerintahan Mesir menetapkan dengan menganut pendidikan sekuler. Pemerintahan Mesir juga menetapkan tanggung jawabnya pendidikan untuk semua warga negaranya.

Kemajuan pemerintahan Mesir mulai kelihatan dengan menetapkan pendidikan untuksemua (education for all). Walaupun demikian pada kenyataannya sebagian besar yang mengenyam pendidikan adalah warga Negara yang memiliki status sosial elit. Pada tahun 1952 ketika ada revolusi Mesir maka cara berpikir warga negaranya sudah berubah. Lebih dari $50 \%$ anak-anak lakilaki mengenyam pendidikan sekolah dasar. Hampir $75 \%$ selama sepuluh tahun warga Negara Mesir mengalami buta huruf. Jumlah yang mengalami buta huruf $90 \%$ dialami oleh orang perempuan.

Semenjak adanya revolusi Mesir pada tahun 1952, pemerintahan Mesir mengalami kemajuan yang sangat luar biasa dalam bidang pendidikan. Secara dramatik sistem pendidikan Mesir berubah yaitu pendidikan untuk semua warganya (education for all). Pemerintahan Mesir mengadakan pendidikan gratis untuk semua warganya. Menteri pendidikan Mesir menambah anggaranya dari tahun 1952-1953 sebesar 3\%, dan lebih dari $5 \%$ pada tahun 1958. Pengeluaran belanja untuk biyaya sekolah meningkat sampai $1000 \%$, pada tahun 1952-1976. Sisi lain warga negaranya meningkat untuk mendaftar sekolah dasar dengan kelipatan 10.000 (PPC ISUE Working Paper No.1, 2004: 29., Abdalla et al, 2006: 18). 


\section{b. Regulasi sistem pendidikan di Mesir}

Regulasi sistem pendidikan pemerintahan Mesir dimonitoring dan dievaluasi oleh kementrian pendidikan. Sistem pendidikan yang dianut pemerintahan Mesir pada akhirnya dengan multi wajah. Sistem pendidikan yang dianut dengan sistem sekuler, pendidikan untuk publik, sistem pendidikan Islam yang dikomandoi di Universitas al-Azhar, pendidikan privat, dan dengan kehadiran orang-orang asing menimba ilmu pengetahuan di Mesir.

Pendidikan sekuler yang diadakan oleh pemerintahan Mesir mencakup pendidikan pra universitas. Pada tingkat pendidikan taman kanak-kanak pemerintahan Mesir juga telah mengadakan sistem pendidikan sekuler. Tidak hanya pada pendidikan taman kanak-kanak pada pendidikan dasar, pendidikan persiapan untuk pekerjaan yang swasta, dan pendidikan menengah juga menganut pendidikan sekuler. Sistem pendidikan. sekuler pada taman kanak-kanak dimulai pada tahun 1990.

Mulai tahun 1991 pendidikan taman kanak-kanak di Mesir mulai memperkenalkan program pendidikan dasar. Tahun 1981 pendidikan dasar dan lembaga pendidikan swasta yang berorientasi pada pekerjaan diberi mandat sebagai pendidikan yang sama dalam levelnya yaitu pendidikan dasar. Pendidikan tersebut pada awalnya ditempuh selama enam tahun. Pada tahun 1988 pendidikan swasta yang berorientasi pada pekerjaan di tempuh 9 tahun dan selanjutnya direduksi menjadi delapan tahun.

Pendidikan menengah di Mesir konsisten dengan melaksanakan pendidikan umum. Pendidikan menengah umum di Mesir merupaka pilar pendidikan yang ada di Mesir. Secara objektif cakupan yang diadakan pada level menengah merupakan persiapan untuk menuju jenjang pada universitas dan ketrampilan hidup. Kurikulum pendidikan umum telah dikenalkan sejak tahun 1991-1992. Pada level tersebut juga dikenalkan tentang aplikasi sain seperti ilmu komputer, perdagangan, pertanian, industri, dan home economic. Jurusan yang ada pada sekolah menengah konsisten pada teknik perdagangan, pertanian, dan teknik industri. Hal yang demikian telah diperkenalkan sejak tahun pertengahan 1990. 
Pemerintahan Mesir konsisten mengadakan pendidikan tinggi pada pendidikan di universitas dan non universitas. Pendidikan tinggi terdiri dari pendidikan umum dan pendidikan al-Azhar. Pendidikan tinggi non universitas pemerintahan Mesir konsisten diadakan di fakultas-fakultas dan di institut. Pendidikan tersebut didesain bagi mahasiswa untuk siap kerja, dan meningkatkan kualitas keilmuan keIslamannya untuk menjadi inovator-inovator di masing-masing Negara (Abdalla et al, 2006: 19).

Selama sepuluh tahun Mesir menerima bantuan dari lembaga bantuan pendidikan seperti World Bank dan USAID. Lembaga - lembaga tersebut memiliki peran yang signifikan terhadap kemajuan pendidikan di Mesir. Bantuan tersebut lebih fokus pada bantuan pendidikan dasar. Alokasi bantuan lebih dari $90 \%$ pada anak yang tidak mau mendaftar ke sekolar dasar. World Bank juga memberikan investasi pendidikan pada teknik pengembangan pendidikan. UNICEF memberikan bantuan pendidikan berkaitan dengan pemberdayaan perempuan. Pemerintahan Jepang memberikan bantuan khusus pada keahlian konstruksi. Walaupun banyak lembaga donor yang memberikan bantuan untuk peningkatan kualitas pendidikan, namun pada level menengah banyak yang tertinggalkan (PPC ISUE Working Paper No.1, 2004: 12).

\section{c. Institusi Pendidikan Islam}

Pemerintahan Mesir menyediakan pendidikan agama sebagai salah satu tanggung jawab dari pemerintah. Menganut pada sistem al-Azhar pendidikan agama diadakan pada pra universitas. Ada dua lembaga yang menangani pendidikan tersebut yaitu institusi umum dan institusi khusus. Sistem al-Azhar menekankan pada pendidikan dasar, pendidikan swasta yang berorientasi pada pekerjaan, dan pendidikan menengah untuk persiapan menuju universitas. Mahasiswa Universitas al-Azhar sampai pada pertengahan tahun 1990 diberi hak menjadi universitas umum. Namun setelah tahun itu Universitas al-Azhar khusus menyediakan pendidikan agama. Universitas al-Azhar selanjutnya mencetak generasi ilmuan-ilmuan agama. Universitas al-Azhar memiliki misi mencetak kader-kader Islam untuk trampil dalam 
bidang ilmu keIslaman seperti bahasa Arab, dan ilmu-ilmu Islam bagi orang asing yang datang menimba ilmu dilembaga tersebut.

Lembaga pendidikan pre universitas al-Azhar berkembang meluas hampir sampai enam puluhan khususnya pada tahun 1991/1992 dan 1998/1999. Kurikulum pendidikan al-Azhar pada umumnya serupa dengan pendidikan umum. Hanya saja kurikulum pendidikannya lebih menekankan pada studi keIslaman. Kurikulum pada pre universitas lebih menekankan pada moral dan nilai-nilai agama berkaitan dengan rukun Islam. Materi-materinya berkaitan dengan pengembangan keimanan, kehidupan nabi, menghafal al-Qur'an dan praktik-praktik pengetahuan tentang ibadah. Murid dituntut untuk hafal 20 juz pada sekolah dasar. Menurut United States Agency for International Development (USAID) tidak ada perbedaan yang menonjol antara sekolah umum dan sekolah yang dikelola dengan sistem al-Azhar (Abdalla et al, 2006: 20).

Uraian di atas dapat dipahami bahwa Mesir merupakan Negara yang sukses dalam melaksanakan program pendidikan untuk warga negaranya ataupun warga Negara asing. Pemerintahan Mesir juga mencanangkan pendidkan untuk semua (education for all). Sistim pendidikan yang anut sistim pendidikan sekuler dan sistem agama. Kesuksesan Mesir dalam melaksanakan program pendidikan juga tidak lepas dari bantuan lemabaga dunia yang ada.

\section{Malaysia}

Jika dibutuhkan untuk mengkaji lebih dalam sebenarnya berbicara globalisasi berpijak pada dua pemahaman kata yaitu globalisasi dan globalism. Akan lebih baik apabila mengkaji dua kata tersebut dibedakan satu persatu. Memahami makna globalisasi lebih mewakili dan representatif apabila globalisasi dikaitkan dengan filsafat materialistik yang memiliki karakter sekuler dan berasal dari Barat. Sisi lain ada yan berpendapat dengan karakter Islam yang universal. Namun demikian globalisasi juga memiliki dampak yang cukup positif pada kehidupan manusia. Lebih dalam lagi mengkaji makna globalism. Globalism dapat dipahami bahwa setiap warga Negara memberikan perhatian extra 
ordinari pada agenda-agenda dunia yang siap bertanding atau siap berkompetisi.

Baik kata globalisasi ataupun globalisme sangat berdampak positif bagi kemajuan studi ke-Islaman maupun pada studi hukum. Pendek kata bahwa globalisasi dapat memberikan konstribusi yang positif pada permasalahan permasalahan sosial yang alami ditingkat dunia. Walaupun demikian tidak dapat dipungkiri bahwa globalisasi juga berdampak negatif pada anak-anak sekolah menengah di beberapa Negara di dunia. Permasalahannya anakanak tersebut belum siap mental mengambil positif dari dampak globalisasi untuk keperluan penyelesaian problem-problem sosial yang dihadapinya.

\section{Sistem pendidikan yang dianut di Malaysia.}

Pendidikan Islam merupakan pendidikan yang sempurna, karena dalam pendidikan Islam ada pendidikan berkaitan kehidupan di dunia dan pendidikan berkaitan dengan akhirat. Istilah pendidikan Islam di Malaysia merupakan istilah pendidikan yang sedang berkembang. Pemerintah Malaysia mengembangkan dua sistem pendidikan yang diadakan untuk warga negaranya. Dua tipe tersebut yaitu pendidikan tradisional dan pendidikan modern. Beberapa pendidikan Islam dilaksanakan dengan sistem pondok pesantren dan ada yang dengan sistem madrasah. Sistem pendidikan tersebut sekarang juga diterapkan di sekolah sekolah umum dan di perguruan tinggi baik institut ataupun universitas. Sistem pendidikan modern dikenalkan dari sumber Barat. Sebagai contoh sekolah yang menganut sistem moderat di Malaysia adalah Malacca Free School sebagai pengaruh dari London Missionary Society. Contoh lain pendidikan yang menganut sistem modern di Malaysia adalah Malay Archipelago. Sekolah ini bertujuan mengakomodasi warga melayu (Kayadibi \& Buang, 2011: 90-91).

Penerapan pendidikan pemerintahan Malaysia cukup mengesankan. Dalam rekam jejak catatan Negara Malaysia dalam hal ekonomi dan pendidikan mengalami perkembangan yang cukup baik. Ditambah lagi pendaftaran pendidikan warga Negara Malaysia pada pendidikan tingkat dasar dan menengah 
cukup tinggi. Pendaftar pendidikan tersebut ditinjau dari gender cukup berkeadilan. Alasan mengapa perkembangan pendidikan di Malaysia cukup mengesankan karena anggaran belanja untuk pendidikan pemerintah Malaysia sebesar 15\% dari total anggaran belanja pemerintah.

Pendapatan pemerintah Malaysia cukup tinggi. Sejak kemerdekaan Malaysia, perkembangan pendidikan di Malaysia memiliki karakteristik tersendiri yaitu pemerintah berusaha mengadopsi pendidikan nasional ekonomi dan mengembangkan sumber daya manusia sesuai dengan kebutuhan pemerintah. Investasi pada pendidikan cukup tinggi berpijak pada keyakinan bahwa kualitas pendidikan akan membawa perbedaan prestasi dan karir bagi warga negaranya. Pemerintah Malaysia menganggarkan bahwa pendidikan merupakan tanggungjawab pemerintahan pusat. Administrasi pendidikan terpusat pada kementrian pendidikan. Untuk tingkat distrik hanya menjalankan kebijakan dari pusat.

Jenjang pendidikan yang ditempuh untuk tingkat elementry (dasar) selama sepuluh tahun. Jenjang pendidikan menengah tingkat bawah selama tiga tahun. Jenjang pendidikan menengah atas selama dua tahun. Jenjang selanjutnya untuk pasca menengah atau persiapan ke universitas selama dua tahun. Jenjang belajar di perguruan tinggi selama empat tahun. Secara otomatis program promosi yang pertama ditempuh selama enam tahun. Namun program promosi ditentukan pada hasil ujiannya. Program promosi pada pendidikan tinggi sangat selektif sekali. Sukses pada pendidikan menengah dapat melanjutkan ke jenjang pendidikan tinggi di universitas ataupun di institut (PPC ISUE Working Paper No.1, 2004: 65).

\section{Tantangan Pendidikan di Malaysia}

Warga Negara Malaysia terdiri dari multi ras. Total populasi pada tahun 2010 terdiri dari 28.3 juta. Jumlah penduduk tersebut terdiri dari warga Negara Malaysia sebanyak $91.8 \%$, dan selebihnya $8.2 \%$ bukan warga Negara Malaysia. Warga Negara Malaysia terdiri dari beberapa etnik grup. Di antara etnik grup tersebut adalah ; bumi putra (67.4\%), China (24.6\%), India (7.3\%), dan yang lain 
(0.7\%). Berdasarkan data statistik Malaysia pada tahun 2010 agama Islam merupakan agama yang dominan yang dianut warga Negara Malaysia. Sebanyak 61.3\% warga Negara Malaysia menganut agama Islam. Warga Negara yang menganut agama Budha sebanyak (19.8\%), agama Kristen (9.2\%), dan Hindu (6.3\%).

Pemerintahan Malaysia memproklamirkan kemerdekaannya pada tahun 1957. Pemerintahan Malaysia mendapatkan warisan dari kolonial Inggris sebagai Negara sekuler dan liberal. Warisan tersebut diterapkan juga dalam sistem pendidikan yang dijalankannya. Kewarga negaraan Malaysia terdiri dari multi ras dan multi keimanan. Pada saat yang sama agama Islam juga diterapkan sebagai bagian dari sistem pendidikan yang dilaksanakan di pemerintahan Malaysia. Pelaksanaan pendidikan keIslaman tersebut dengan sistem madrasah ataupun pondok. Pelaksanaan pendidikan tersebut juga dilaksanakan dalam komunitas ataupun pribadi dengan cara privat.

Setelah merdeka pemerintahan Malaysia menetapkan pelaksanaan pendidikannya dengan sistem pendidikan religius Islam. Sistem pendidikan tersebut diterapan di sekolah dasar dan sekolah menengah. Bagaimanapun sistem pendidikan warisan dari kolonial Inggris tetap menjadi bagian dari sistem pendidikan yang dijalankannya sampai tahun 1980 . Selanjutnya pemerintahan Malaysia melaksanakan uji coba dengan sistem kurikulum terintegrasi yang pada awal pembelajaran dilaksanakan setengah hari menjadi sehari penuh. Untuk memastikan pelaksanaan kegiatan pembelajaran dengan terintegrasi pemerintahan Malaysia memastikan dengan pelaksanaan pembelajarannya dengan materimeteri ulumul naqliyah (ilmu-ilmu tradisional), dan ulumul aqliyah (ilmu-ilmu modern) (Hasyim, 2014: 178).

Pemerintahan Malaysia telah berhasil menerapkan kebijakan sistem pendidikan dasar sebelas tahun untuk semua. Pendidikan dasar sebagai pendidikan yang utama untuk semua telah dicanangkan sejak tahun 1990. Selanjutnya partisipasi pendaftaran pendidikan pada tingkat menengah pada tahun 1960-1995 yang paling tinggi berkisar antara 10\%-56\%. Sisi lain partisipasi warga Negara Malaysia untuk mengenyam pendidikan tinggi berkisar $0.4 \%-3.7 \%$ selama satu periode. 
Kualitas pendidikan yang dijalankan pemerintahan Malaysia cukup bagus. Kondisi tersebut ditunjang dengan sumber daya pendidiknya sesuai dengan kompetensi dan dapat mengaplikasikan fasilitas teknologi dan multi media serta penerapan kurikulum sesuai dengan kebutuhannya. Apalagi kualifikasi pendidik yang mendidik di sekolah tingkat menengah hampir sama dengan tingkat kualifikasinya yang mengajar di perguruan tinggi. Kurikulum pendidikan yang dilaksanakan di sekolah menengah adalah kurikulum yang berisikan persiapan anak didik untuk siap bekerja, apabila setelah lulus sekolah nanti.

Kebijakan reformasi pendidikan pemerintahan Malaysia mulai dicanangkan sejak tahun 2000. Permasalahannya karena pendapatan Negara cenderung menurun. Hal tersebut karena melemahnya investasi dalam dunia pendidikan. Walaupun keadaan demikian pemerintah terus mencanangkan meningkatkan kualitas pendidikan khususnya di Malaysia bagian timur. Rasionalisasi investasi pendidikan pada tingkat menengah lebih menekankan pada pendidikan teknik dan vokasional. Keadaan yang demikian menjadikan lulusan pendidikan menengah diterima di pasar kerja. Untuk meningkatkan kualitas mutu pendidikan pemerintahan Malaysia juga melaksanakan pendidikan politeknik. Di samping itu untuk memperkuat mutu pendidikan, pemerintahan Malaysia dalam mengoperasikan pelaksanaan program pendidikan dengan perencanaan dan manajemen yang matang.

Lembaga bantuan yang membantu pelaksaan pendidikan pemerintahan Malaysia berasal dari Negara Jerman. Lembaga tersebut bernama The German Cooperative Agency for Development. Lembaga tersebut memberikan pelatihan-pelatihan pekerjaan di bidang industri pada tingkat menengah secara intensif baik ketrampilan industri tingkat dasar ataupun atas.

Kekuatan dan kelemahan persiapan lulusan lembaga pendidikan dalam dunai kerja terus menjadi kajian yang intensif pemerintahan Malaysia. Pemerintahan Malaysia telah menyiapkan sekolah pendidikan teknik dan vokasional dengan baik. Lebih dari enam puluh teknik dan vokasional diselenggarakan dalam institusi pendidikan. Pendidikan teknik dan vokasional telah terintegrasi pada kurikulum pendidikan menengah. Pendidikan 
teknik dan vokasional tingkat tinggi diajarkan pada pendidikan di politeknik. Di antara politeknik yang ada di Malaysia adalah MARA Instutut Teknologi dan The Tunku Abdul Rahman College. Lembaga tersebut merupakan lembaga pendidikan profesioanal yang memberikan sertifikat kepada mahasiswa lulusan lembaga tersebut setara diploma (PPC ISUE Working Paper No.1, 2004: 66-67).

\section{Institusi Pendidikan Islam di Malaysia}

Di samping agama Islam yang ada di wilayah Asia bagian selatan juga ada agama lain yaitu Hindu dan Budha. Warisan yang lain di wilayah Negara bagian Asia selatan adalah Negara tersebut bekas jajahan tiga Negara yaitu Ingris, Belanda, dan Perancis. Hal yang demikian maka agama Islam di wilayah tersebut sudah barang tentu telah berinteraksi dengannya dan terpengaruh dengan budaya dan tata pola pikirnya. Tidak ketinggalan pula seperti Negara Malaysia yang warga negaranya juga terdiri dari multi ras dan multi keimanan. Malaysia juga bekas jajahan negara Inggris.

Sudah barang tentu keadaan yang demikian yang terjadi berpengaruh terhadap sistem pendidikan yang dijalankan oleh pemerintahan Malaysia. Pemerintahan Malaysia tidak dapat melepaskan begitu saja pengalaman dijajah oleh Inggris. Lama waktunya warga Negara Malaysia berinteraksi dengan Inggris pada akhirnya juga berdampak pada sistem pendidikan yang dijalankannya yaitu pendidikan sekuler. Walaupun pada akhirnya sistem pendidikan yang dijalankannya dengan sistem pendidikan Islam. Dalam kajian kajian keilmuan para ilmuan Islam Malaysia selalu memberikan kritik antara interaksi Islam dan pra Islam. Selanjutnya bagaimana sikap penerimaan para pembaharu warga Negara Malaysia dengan pada keadaan yang dihadapinya (Mardman et al, 2011: 113-114).

Diskursus tentang dunia Islam di Melayu di Asia bagian selatan telah dikaji oleh Clifford Geetz sejak tahun 1960. Dia seorang ilmuan antropologi dari Amerika dan William Roff seorang sejarawan dunia Melayu. Menurutnya yang memproduksi ilmu pengetahuan di wilayah tersebut adalah interaksi agama Islam dan Muslim Melayu. Geertz menjadi terkenal setelah dia meneliti 
Islam dan ditulis hasil penelitiannya memperbandingkan antara Islam di Indonesia dan Islam di Maroko. Di Indonesia Greetz menekankan kajian realita Islam dalam kehidupan di Indonesia bermesraan dengan orang-orang Jawa. Dia lebih terkenal ketika membagi tipologi muslim Jawa yaitu Islam abangan, priyayi dan santri.

Roff menulis artikel di Perancis pada jurnal Archipel. Dia menulis tentang ketidakjelasan Islam. Walaupun demikian tulisannya tidak direspon sebesar seperti penelitiannya Geertz yang menjadi terkenal. Roff menekankan bahwa budaya yang memasuki realita kehidupan muslim. Artinya bahwa ajaranajaran Islam juga telah banyak terpengaruh oleh budaya-budaya setempat. Di Negara Melayu Roff menggambarkan bahwa Islam menjadi sistem politik dalam bentuk kerajaan. Hasil kajian Islam di Melayu oleh Roff dan Geertz disajikan dalam bentuk cerita (Mardman et al, 2011: 114-115).

Sampai sekarang apabila berbicara masalah pendidikan Islam dapat dikatakan kurang sukses, kalau tidak mau dikatakan gagal. Permasalahannya sistem pendidikan Islam tidak dapat membedakan antara sikap dan perilaku siswa untuk membangun etika moralnya. Pernyataan tersebut bukan berarti tidak ada argumen. Pertanyaan tersebut didukung dengan beberapa alasan. Pertama bahwa ilmu agama tidak dapat memasuki kognitif yang memiliki makna dan nilai. Ilmu agama hanya menekankan pada pengetahuan. Kedua pendidikan agama tidak dapat bekerjasama dengan program pendidikan non religius. Ketiga pendidikan Islam kurang relevan berkaitan dengan perubahan sosial, sehingga siswa tidak dapat mengimplementasikan dalam kehidupan sehari-hari. Untuk menjawab keadaan yang demikian maka para pendidik harus berani untuk melakukam move on atau hijrah. Hijrahnya para pendidik untuk merekonstruksi metodologi dari model pendidikan dogmatis doktrin dan tradisional menuju dinamis dan kontekstual (Asrori, 2015: 589).

Sistem pendidikan pemerintahan Malaysia dilaksanakan dengan sistem klasik dan modern. Pendidikan yang dilaksanakan di Malaysia dengan sistem pendidikan Islam berbasis pesantren. Transformasi pengetahuan agama Islam melalui pendidikan 
madrasah (Nidzami Madrasah System). Melalui sistem tersebut siap memperkenalkan dunia Melayu. Jika konsep globalisasi dipahami dapat menukarkan informasi antara yang satu dengan yang lain, maka pemikiran pembaharu seperti Jamaludin alAfghani (1839-1907), Muhamad Abduh (1849-1905) juga dapat dipertukarkan pada generasi-generasi muslim berikut untuk pembaharu-pembaharu Islam sebagai seorang mantan anak didik dengan sistem madrasah nidhami.

Ada kesan bahwa pendidikan Islam dengan sistem pondok pesantren hanyalah penanaman doktrin agama dari guru pada anak didiknya. Pendidikan sistem pesantren terkesan monoton tidak dialogis. Berbeda dengan sistem madrasah nidzami selangkah lebih maju. Dalam pendidikan tersebut diajarkan prinsip-prinsip pengajaran yang normatif, tetapi juga mengkaji dari sisi budaya dan sosiologinya, sejarahnya dan interaksi global baik secara empirik ataupun tidak empirik. Perubahan pendidikan Islam di Malaysia dari sistem pesantren ke madrasah nidzami yang berbasis kajian normatif empirik serta tuntutan sosiologi budaya, globalisasi yang sedang dialami di dunia. Hal yang demikian mendorong pada para pendidik bahwa anak didiknya nanti dapat diterima dan bersaing dengan yang lain pada era globalisasi (Kayadibi \& Buang, 2011: 91-92).

Pendidikan yang diadakan oleh pemerintahan Malaysia menganut sistem paralel yaitu sekolah nasional dan sekolah agama Islam. Dua sistem sekolah tersebut dikelola oleh kementrian pendidikan. Tingkatan sekolah terbagi menjadi tiga bagian. Pertama sekolah dasar siswanya terdiri dari tingkat 1-6. Tingkat menengah bawah terdiri dari tingkat 7-9. Tingkat menengah atas terdiri dari tingkat (10-11). Sekolah agama di Malaysia dapat dibagi menjadi tiga katagori. Pertama sekolah agama kebangsaan (national religious schools). Kedua sekolah agama negeri (state religious schools), dan ketiga sekolah agama rakyat (Islamic Private schools).

Pembiayayaan sekolah agama kebangsaan semua ditanggung oleh pemerintahan Malaysia pusat. Anak-anak yang sekolah pada sekolah tersebut memiliki nilai prestis. Keadaan yang demikian menjadikan penerimaan murid sangat selektif. Sistem 
penerimaan murid pada sekolah agama kebangsaan dilaksanakan tes ditanggung oleh kementrian pendidikan. Sekolah agama rakyat. Pembiayayaan sekolah tersebut dibantu pemerintah dan dewan pendidikan ataupun sumber sumber dari yayasan.

Sekolah agama Islam di Malaysia bahasa pengantarnya menggunakan bahasa Melayu. Bahasa Inggris juga merupakan bahasa yang wajib digunakan dan menjadi bahasa pengantar dalam mengajar. Kurikulum yang diajarkan pada sekolah agama tingkat dasar berkaitan dengan al-Qur'an yang menggunakan bahasa Arab. Sekolah Islam secara formal di Malaysia dilaksanakan secara full time sampai level sekolah menengah. Kurikulum yang diajarkan dalam sekolah agama meliputi belajar al-Qur'an hadist dan hukum-hukum Islam. Beberapa sekolah melayani dengan sistem penginapan atau dikenal dengan boarding school. Sekolah agama Islam di Malaysia menekankan pada perilaku kepribadian berdasarkan norma-norma agama Islam dan norma-norma masyarakat Melayu. Untuk muslim dan non muslim pendidikan moral terpusatkan pada jenjang pendidikan dasar. Sekolah tersebut didesain untuk pengembangan kepribadian seperti kemandirian, kepercayaan diri, aktualisasi diri, spiritualitas, disiplin, dan cinta terhadap ilmu pengetahuan (PPC ISUE Working Paper No.1, 2004: 68-69).

Paparan di atas dapat disimpulkan bahwa Malaysia termasuk Negara yang sukses yang menyelenggarakan pendidikan agama Islam dan pendidikan umum. Sistim pendidikan yang dijalankan adalah dengan sistim pendidikan tradisional pesantren dan berkembang menjadi sistim madrasah nidzami. Sistim pendidikan yang lain yang dilaksanakan di Malaysia adalah sistim pendidikan modern.

\section{Psikologi Positif dalam Perspektif Pendidikan Islam}

Islam merupakan agama yang universal. Islam merupakan agama sepanjang zaman sehingga Islam tidak akan mengalami kebuntuan untuk menjadi ajaran hidup manusia yang turun dari sang Pencipta langit dan bumi yaitu Allah. Menurut Mehden et al (1985: 71-72) bahwa kebangkitan Islam ditandai dengan lahirnya pemikir-pemikir Islam yaitu Muhamad bin Abdul Wahab dari 
Arab Saudi pada abad 18 (pendiri gerakan wahabi). Tokoh yang lain Sayid Muhamad Ali bin Sanusi dari al Jazair pada abad ke 19 (pendiri gerakan sanusiah). Jamaludin al-Afgani pembaharu pada abad ke 19. Zia Gikalp dari Turki pada permulaan abad ke 20. Mula Hadi Sabzirawi dari Iran pembaharu pada abad 19 dan Syeikh Wali Allah Dilhawi dari India pembaharu pada abad 18.

Walaupun ada perbedaan idiologis yang cukup berarti antara tokoh pembaharu misalnya al-Wahabi dan al-Sanusi yang menekankan pada kemurnian konservatif. Sisi lain al-Afghani dengan shah Wali Allah yang menekankan pada komitmen pada penafsiran progresif berdasarkan akal dan pengetahuan. Walaupun demikian mereka tidak memperdebatkan. Mereka memiliki tujuan mulia yaitu mengembalikan kebesaran agama mereka yaitu agama Islam.

Di Asia Tenggara pada permulaan abad 20 muncul intelektual Islam yang cemerlang yaitu Daud Patani, Tok Kenai, Sayid Syeikh al-Hadi dan Tahir Jamaludin. Walaupun tokoh tokoh tersebut kurang dikenal seperti tokoh-tokoh dari Timur Tengah dan anak benua India. Mereka semua merupakan pembaharupembaharu hukum Islam dan konsep-konsep Islam. Secara khusus di Malaysia mereka adalah orang-orang yang menghendaki kembali kepada al-Qur'an dan Hadist.

Uraian di atas dapat dilihat secara saksama bahwa Islam memang agama sepanjang zaman. Setiap masa ada tantangan dan problema disitu muncul seorang pemikir ataupun cendekiawan muslim yang mampu menjawab dan menyelesaikan permasalahan tersebut. Hal tersebut menunjukan bahwa agama Islam di era global tetap dapat bersanding bermesraan bekerja sama tanpa menghilangkan substansi akidah Islamiyah ataupun problem sosial.

Menurut Mehden et al (1985: 248-249) bahwa sejak awal abad 19 pemikiran sosio politik intelektual di Mesir dan Negara-negara Islam bagian Timur didominasi oleh pertentangan antara golongan nasional Mesir sekuler dengan golongan Islam. Dengan terjadinya revolusi Mesir pada tahun 1952 sosialisme Arab Nassir menggantikan nasionalisme sebagai idiologi politik sekuler dominan dan mengalahkan idiologi Islam. Keadaan yang 
demikain mendapatkan sorotan dari dunia ketiga terutama dari kalangan dunia Arab tersendiri.

Menurut gerakan Islam kontemporer di Mesir bahwa dia menantang asumsi baru yang menganggap bahwa Arabisme maupun Islam sama-sama tertutup. Gerakan tersebut memberikan saran Islam untuk tidak menjadi oposisi struktural terhadap Arabisme. Gerakan pembaharuan di Mesir lahir ketika lahir Jemaat al Syubban al-Muslimun yang didirikan oleh Hasan al Bana pada tahun 1927. Pada tahun 1928 Hasan-al-Bana melahirkan gerakan perhimpunan persaudaraan Muslim.

Islam merupakan agama sekitar $55 \%$ penduduk Malaysia. Penduduk lainya di Malaysia merupakan keturunan China dan India. Mayoritas Islam di Malaysia adalah penduduk melayu. Orang-orang melayu mencerminkan sebagai orang-orang yang ritualistik terhadap keyakinannya. Penduduk muslim Malaysia juga rentan adanya perpecahan antar umat Islam itu sendiri. Masalahnya warga negaranya juga terdiri dari multi ras. Ada yang mengendaki Negara untuk tidak menekankan kehidupan pluralism. Sisi lain ada tuntutan hukum Islam untuk diberlakukan juga kepada non muslim. Dinamika yang demikian apabila tidak dikelola dengan baik, pada waktunya akan menjadi perselisihan dan menjadi bom waktu (Mehden et al, 1985: 121-122).

Ulasan di atas apabila dipahami secara mendalam dapat disimpulkan Islam walaupun dalam keadaan terpuruk selalu ada yang bangkit sebagai tokoh yang memberikan solusi yang lebih baik. Para tokoh tersebut terlahir dari orang-orang yang terdidik. Dapat disimpulkan bahwa tokoh yang tampil secara psikologis dia memiliki kepercayaan diri akan kehidupan yang lebih baik secara individu ataupun kolektif. Kondisi yang demikian apabila dikaji mendalam orang tersebut memiliki konsep psikologi positif yang kuat.

Ulasan di atas bahwa seseorang yang memiliki konsep hidup psikologi positif orang tersebut akan mendapatkan kesejahteraan psikologis yang baik. Tokoh tokoh pendidikan Islam yang ada di Mesir maupun di Malaysia merupakan tokoh yang memiliki aktivitas yang positif dan kesejahteraan psikologis yang baik well being. Dalam jurnal How do simple activities increase 
well being? Dijelaskan bahwa seseorang perbuatan positif yang intensif akan meningkatkan well being seseorang. Hasil penelitan menunjukan bahwa seseorang dapat meningkatkan kebahagiaan dengan cara melakukan perbuatan yang positif secara intensif. Contohnya adalah berekspresi dengan selalu memanjatkan puji syukur atas nikmat yang diperolehnya dan melakukan kebaikan. Jurnal tersebut membahas tentang model penelitian dengan variabel moderator. Variabel variabel tersebut dalam model penelitiannya adalah akativitas positif yang terdiri dari model aktivitas positif, aktivitas positif yang utama, kepribadian yang utama, dan aktivitas kepribadian yang baik sebagai variabel moderator berpengaruh terhadap kesejahteraan psikologis (Lyubomirsky \& Layous, 2013: 57).

Ditelaah lebih mendalam di Mesir ataupun Malaysia dalam perkembangannya tentang pendidikan Islam dalam menghadapi tantangan zaman selalu ada yang tampil untuk menjadi pemecah masalah. Inti dari kemajuan suatu Negara Negara tersebut juga terlihat dari kemajuan pendidikan yang diselenggrakannya. Dapat dikata baik bagi Negara ataupun masing-masing individu pendidikan merupakan investasi demi kemajuan bangsa dan kesejahteraan warga negaranya.

Apabila dicermati dengan saksama, maka tokoh-tokoh pembaharu pejuang pendidikan yang lahir di Mesir ataupun di Malaysia merupakan sosok seseorang yang memiliki well being yang baik. Keadaan yang demikian merupakan kekuatan manusia tersendiri yang bersumber dari kekuatan psikologi positif yang dimilikinya. Di antara hal - hal untuk meningkatkan kesejahteraan psikologis seseorang dengan teknik The Positive Educational Practices (PEPs). Teknik teknik tersebut adalah orang tersebut memiliki kompetensi sosial dan emosional. Seseorang yang memiliki kompetensi tersebut orang tersebut memeiliki keefektifan dalam interaksi sosial dan emosinya. Orang tersebut dalam mempelajari sesuatu fokus pada kurikulum nilai-nilai sosial. Sebagai contoh orang tersebut respek pada persoalan manusia, dapat bekerjasama, menerima adanya perbedaan, jujur, inklusi, bersahabat, dan memiliki rasa belas kasih yang tinggi (Noble \& McGrath, 2008: 122). 
Apabila ditelaah lebih dalam lagi tokoh ilmuan Islam yang menjadi inspirasi warga Negara Mesir ataupun Malaysia untuk bangkit pasti mereka memiliki kehidupan yang baik secara psikologis dan baik secara jasmani. Walaupun dalam hitungan harta mereka bukan seorang hartawan. Namun dia juga mengiginkan kehidupan yang baik bagi warga negaranya dan warga masyarakat. Menurut Ward \& Schwartz et al (2004: 57) seseorang yang terorganisir secara intrinsik nilai-nilai kehidupan yang baik dan bahagia maka orang tersebut akan bahagia. Hal yang demikian menujukan bahwa psikologi positif membawa seseorang untuk sukses dalam mengerjakan sesuatu. Nilai-nilai yang dimiliki seseorang untuk tujuan kehidupan yang baik akan mengiringi apa yang menjadi visinya dalam bekerja dan kehidupannya.

Untuk merubah kehidupan seseorang baik secara individu ataupun kelompok, orang tersebut harus mulai dapat membedakan antara berpikir positif negatif dan berpikir yang benar. Pemikiran seseorang apabila digambarkan naik turun seperti suara piano. Seseorang yang memainkan piano terkadang tidak harmoni, tidak imbang dan tidak enak didengarkan. Permasalahannya seseorang yang memainkan piano terkadang dalam memencet alat musik tersebut juga tidak seimbang. Keadaan yang demikian apabila ada seorang guru musik, maka akan berkata bahwa sebenarnya saudara dapat bermain piano dengan baik, cuma saudara tidak paham cara memainkannya.

Impian para tokoh ilmuan untuk membangun Negara dari keterpurukan menuju kemajuan yang sejahtera dimiliki oleh orangorang yang memiliki kekuatan ketrampilan, ilmu pengetahuan dan bakat. Tidak semua orang terpanggil untuk melakukan hal yang demikian berpikir untuk kemaslahatan bangsanya dan dirinya. Sebagian besar orang berpikir hanya untuk dirinya. Orang orang yang mau membangun masyarakat dan bangsanya seperti dalam bidang pendidikan Islam di Mesir ataupun Malaysia merupakan orang-orang yang memiliki pemikiran dan kepribadian positif.

\section{Simpulan}

Paparan hasil review dari berbagai sumber bacaan buku ataupun jurnal di atas dapat disimpulkan bahwa globalisasi 
bukanlah penjajahan. Globalisasi merupakan dampak dari perkembangan kemajuan peradaban dunia yaitu ilmu dan teknologi. Globalisasi dapat memberikan dampak positif dan negatif. Dampak positif dari globalisasi orang akan mudah berinteraksi, mengenal, bertransformasi, dan belajar antar Negara dalam berbagai bentuk seperti bahasa, budaya, ilmu pengetahuan, ekonomi, hukum, dan politik. Dampak negatifnya adalah adanya interaksi bebas antar budaya sehingga apabila seseorang tidak siap secara iman dan mental, maka dapat melahirkan perilaku negatif.

Pelaksanaan pendidikan Islam di Mesir ataupun Malaysia cukup baik. Buktinya kedua Negara tersebut telah melasanakan pendidikan untuk semua (education for all). Sisi lain kedua Negara juga cukup memberikan anggaran yang cukup besar untuk penyelenggaraan pendidikan Islam. Pemerintahan Mesir dalam pelaksanaan pendidikan menganut sistim pendidikan sekuler dan Islam. Begitu juga pemerintahan Malaysia dalam pelaksanaan pendidikan menganut sistim tradisional dan modern.

Kebangkitan umat Islam ataupun respon umat Islam dalam menanggapi tantangan dan permasalahan pendidikan Islam cukup positif. Para penyelenggara pemerintah ataupun ilmuan terus merespon permasalahan tersebut dengan kepribadian yang positif, dan berpikir positif. Bentuk dari penyelenggara pemerintah mendukung penyelenggaraan pendidikan Islam di Malaysia ataupun Mesir dengan memberikan anggaran yang cukup memadai. Hal yang demikian merupakan bagian dari kajian psikologi positif. Kondisi yang demikian menjadikan hasil yang nyata dari konstribusi para penyelenggara pemerintah ataupun ilmuan Islam sehingga pelaksanaan pendidikan Islam di Mesir dan Malaysia cukup baik. 


\section{DAFTAR PUSTAKA}

Al-Qur'an dan Terjemahannya.1989. Jakarta: Yayasan Penyelenggara Penterjemah al-Qur'an, Lajnah Pentashih Mushaf AlQur'an Deartemen Agama Republik Indonesia.

Abdalla, Amr, Abu-Nimer., Muhammed, Nasser., Ilham, Kadayivic, Aysa., Kunkle, Lynn., \& el-Kilani, Saber.2006. Improving the Quality of Islamic Education in Developing Countries: Inovative Approaches, Creative Associates International Inc.

Asrori, Ahcmad.2015. Islamic Education Development Strategy In Facing The Global Challenges. International Journal of Science and Research. Vol.4, Issue. 11: 2319-7064.

Goddadr, Hugh., \& Khamis, Sahar.2012. Building A Shared Future: Islam, Knowledge, and Innovation, British Councils: University of Cambridge.

Hashim, Rosnani. 2014. Reforms in Islamic Education International Perspective, Edited by Charlene Tan, New York: Bloomsbury.

Kayadibi, Saim., \& Buang, Ahmad Hidayat.2011. The Role of Islamic Studies in Muslim Civilization in The Globalized World: Malaysian Expereince. Jurnal Hadhari, 3. (2). 83102.

Mardman, Hasan., Samsul, A.B., \& Aziz, A.2011. Islamic Studies and Islamic Education in Contemporary Shoutheast Asia, Edited by Kamaruzzaman Bustamam \& Ahmad Patrick Jory, Malaysia: Yayasan Ilmuan.

Mehden, Fred R van der., Muzafar, Chandra., \& El-Gandi, Fadwa.,.1985. Perkembangan Modern dalam Islam, Jakarta: Yayasan Obor Indonesia.

Noble, Toni., \& McGrath, Helen. 2008. The positive educational practices framework : A tool for facilitating the work of educational psychologist in promoting pupil well being, Educational \& Child Psychology, Vol.25, No.2, The British Psychological Society, 119-134. 
Lyubomirsky, Sonja., \& Layous, Kristin. 2013. How do simple activities increase well being?, Psichological Science, Unversity of California.

PPC ISUE Working Paper No.1.2004. Strengthening Education in the Muslim World Country Profiles and Analysis, Development Experience Clearinghouse (USAID).

Prinsloo, Karel., Corrouge, Magali., Chakma, Tutu Mani., Benavot., \& Sayeed, Anima.2015. Educational For All (EFA) 20002015 Achievement and Challengges, UNESCO.

Saliyo. 2015. Islamic Motivation, Proceeding, Konsorsium Keilmuan Psikologi PerguruanTinggi Keagamaan Islam (PTKI): Fakultas Ilmu Sosial \& Humaniora UIN Sunan Kalijaga Yogyakarta.

Saliyo. 2017. Bimbingan Konseling Spiritual Sufi, dalam Psikologi Positif, Yogyakarta; Galang Press.

Ward, Andrew., Kasser, Tim., \& Schawartz, Barry.2004. Positive Psychology in Practice, Edited by P.Alex Linley and Stephen Joseph, Canada: John Wiley \& Sons. 